\title{
BARRIERS TO DISCIPLESHIP IN THE MANDARIN-BASED CHURCHES
}

\author{
Thio Donald Sugiarto \\ Evangelical Theological Seminary of Indonesia - Surabaya \\ E-mail: thiodonaldsugiarto@sttii-surabaya.ac.id
}

\begin{abstract}
Discipleship today has again become a principal concern, was greeted with positive and implemented practically in the Lord's church, including the church-based mandarin which will be the object of research journal. However the fact is, after going through a preliminary study in the form of informal conversations with some of the Servants of the Lord and of the Assembly representing some church-based mandarin, the authors noticed that even though discipleship approved by a majority of the Servant of the Lord as an important thing that must be done, however there are still many of the church who have not done it in a concrete way in real life. Seminar after seminar and training for the sake of training has been held, in great demand and was followed by thousands of people from dozens of even hundreds of church, however only a handful of the church has been run in real time and sustainable.

Considering the importance of discipleship which is the great mission of Jesus, not just an option or optional, even though there are many aspects that can be examined in the subject of discipleship, the authors will focus his research on the obstacles that may arise in the implementation of discipleship practically in the church, in particular that based on mandarin. Therefore, the authors wanted to examine further, the first about the essence of discipleship itself, and continued with research on the constraints, obstacles and challenges that make this discipleship can't be implemented in churches, in particular that based mandarin where the author to worship and serve.
\end{abstract}

Keywords: Discipleship,Church,Barriers,Mission.

\section{INTRODUCTION}

"Discipleship" is actually not a new thing in christianity. The lord Jesus ' own disciple in His ministry in this world, and even give strict orders through the great commission to make disciples as written in Matthew 28:19-20 (ITB) : "go therefore and make disciples of all nations, baptizing them in the name of the Father and of the Son and of the Holy Spirit, and teaching them to obey everything I have commanded you. And lo, I am with you alway, even unto the end of time." Verse the great mission during this indeed be understood as the basis of the preaching of the Gospel, and indeed so. However, when examined more in 
depth, the focus is not just the preaching of the gospel to make all the nations to know Christ and to baptize them, but rather are much longer which made all the nations of the followers of Christ, and it has the quality of a disciple. Referred to as the people of Christ have the quality of a disciple is a believer who dedicates his whole life as a living sacrifice for the Lord [1] the concept of understanding the great mission of the same, which is known in terms of discipleship in the present, has actually been understood and built since the time of the New Testament based on the example of Christ, especially those affirmed by the Apostle Paul, as written in some parts of the Bible, are as follows: For though ye have ten thousand educators in Christ, you do not have many fathers. Because I am in Christ Jesus I became your father through the Gospel I proclaim to you. I exhort you, be imitators of me. (1 Cor. 4:15-16 ITB) What you have heard from me among many witnesses, commit these to people who can be trusted, which is also competent to teach others. (2 Tim. 2:2 ITB).

Thus it is clear that discipleship was modeled and commanded by Jesus and continued by His disciples. Therefore it is very important because it is a divine command, as said by Cuba: There is no higher calling in life than to embrace the divine directive to 'make disciples of all nations'. (There is no higher calling in life than to meet the divine command to make disciples of all nations) [2] However, in the course of time, christianity without discipleship turned out better master the mindset of most of the church today.

Dietrich Bonhoeffer was a Lutheran theologian of Germany (1906-1945), says that the things of the underlying mindset of the church of the present waived discipleship in any form, such as written as follows : The christology of the abstract, the order of nature doctrine, religious knowledge to the grace and forgiveness of sins are spurious, make discipleship becomes irrelevant. In fact, everything is blatant waived discipleship in any form, and in fact opposed the whole concept of following Jesus [3].

So it may be said that discipleship is no longer quite relevant for Christians today. God should be the center of the life of the believer, instead exploited in such a way by the people believe as said by Horton thus: God used as a source of personal power and instead recognized, worshiped and believed; Jesus Christ is a counsellor with a good work plan for our victory and not the Savior who has reached the victory for us; salvation is a matter of live the best life we this moment than to be saved from the judgment of God by God himself; and the Holy Spirit is the power that can channel 
the energy that we need to become our best selves [4] So based on that statement it may be said that the mindset that was awakened in the person believes to be a mindset that is based on the concept of the Christology of the abstract, the order of the doctrinal egocentric, as well as the degradation of the meaning of grace and the remission of sins, that will make obedience to Christ to be reduced even no longer relevant. Thus as it was told by Bonhoeffer that christianity without discipleship is the same with christianity without Christ: "Christianity without the living Christ is inevitably Christianity without discipleship, and Christianity without discipleship is always Christianity without Christ [5] While the Hull to explain it thus: Culture of the church in the west - including Australia, New Zealand and South Africa - have been widely accept the idea of christianity without discipleship: a Person can be a Christian without having to make any effort to subjugate themselves to Christ and follow Him [6]. Horton further strengthen the statement by stating that Christ is increasingly reduced to a mascot or symbol of a subculture and industrial live [7], and when this happens, it will make the church more and immerse yourself with the culture and traditions of the surrounding. Value-the value of morality between the truth of God's Word and the culture or tradition of the amalgamated into one. In time this will make christianity agree to cultural values and traditions that actually do not coincide even contrary to the truth of God's Word.

A variety of conditions as outlined diataslah the threat to the life of christianity today, where the essence of christianity are increasingly experiencing the shift in the meaning from time to time. Discipleship as one of the main points and important in the lives of believers are increasingly neglected.

\section{RESEARCH METHOD}

This study uses a descriptive qualitative research. Bogdan and Taylor defines qualitative research as a procedure research that produces descriptive data in the form of words written or spoken of the people or the observed behavior.

This study aims to find the new knowledge of a phenomenon the results of this study, as also described by Sandjaja and Heriyanto as follows: the Methodology of qualitative research has the main objective to collect descriptive data describing the object of the research in detail and depth with the intent of developing the concept or understanding of a phenomenon.[8]

Meanwhile Sugiyono explain it thus: the end Result of qualitative research, ... must also be able to produce information that is meaningful, even a hypothesis or a new science that can be used to help solve 
problems and improve human life.[9]

In this case I specifically want to find out clearly the things that hinder the implementation of discipleship in real terms in the church-the church-based mandarin, so it can present information or theories that are expected to be useful for the church-the church that has the background and characteristics are similar to the church-the church that became the object of this study.

\section{RESULTS AND DISCUSSION}

First of all, the author will describe the preparations that have been done in the preinterview. And before carrying out a formal interview, the author will be presented also the analysis of the preliminary studies that have been collected from multiple respondents informally at the beginning of the study.

Then the author will present the results of formal research through interviews to 6 people respondents. The presentation will begin with an explanation of the profile of respondents, which is then followed by a summarization of the results of the interview, followed by the reduction of irrelevant data, then the data-relevant data that have been collected are then compiled and presented in a narrative.

After respondents for the sake of the respondents completed presented, then the results of the research data will be reviewed and then built a or a series of theory-theory from the data collected in this study. Theory-theory is then expected to provide inputs to decision-making strategic or tactical and practical for the authorities in the implementation of discipleship to carry out the great commission of Jesus Christ. These theories are expected to be used as a basis to be tested and further developed through further studies.

\section{Interview Preparation}

As already described in the previous chapter, that the preparation of general pre interview has been conducted during the months of July to early August before the first interview was held. However, preparation for the preparation done ahead of each interview with each respondent to anticipate the possibility of the development of the interview based on the characteristics of the respondents.

This can be done given that the author has conducted an initial review through discussions on an informal basis, with either a prospective respondent or other parties that may provide information about the profile of the respondents.

General preparation is done is compiled a list of the main questions that can then be further developed according to the needs at the time of the interview. 


\section{Description Of The Data}

Furthermore, the authors will begin to describe the data obtained through the interviews with the respondents for the sake of respondents. In recording the results of the interview, the author will do the codification and process the data as described as follows:

\section{Table 4.1}

\section{Codification and Data Processing Interview}

\begin{tabular}{|c|c|c|c|}
\hline RESPONDENT & $\begin{array}{c}\text { COLLECTION } \\
\text { DATA }\end{array}$ & GROUPING DATA & $\begin{array}{c}\text { REDUCTION } \\
\text { DATA }\end{array}$ \\
\hline \multirow{4}{*}{$\begin{array}{l}\text { Respondents } 1= \\
\text { AY } \\
\text { Code R1 }\end{array}$} & $\begin{array}{l}\text { Data } 1 \\
\text { Code D1 }\end{array}$ & $\begin{array}{l}\text { Group } 1(\mathrm{~K} 1) \\
\text { consisting of D1 and D3 }\end{array}$ & $\begin{array}{l}\text { Data } \mathrm{D} 2 \text { is } \\
\text { reduced }\end{array}$ \\
\hline & $\begin{array}{l}\text { Data } 2 \\
\text { Code D2 }\end{array}$ & $\begin{array}{l}\text { Group } 2(\mathrm{~K} 2) \\
\text { consists of a D4 }\end{array}$ & \\
\hline & $\begin{array}{l}\text { Data } 3 \\
\text { Code D3 }\end{array}$ & & \\
\hline & $\begin{array}{l}\text { Data } 4 \\
\text { Code D4 }\end{array}$ & & \\
\hline And so on & And so on & And so on & And so on \\
\hline
\end{tabular}

The Data that has been codified, reduced and grouped is then analyzed and examined the relationship between data with one another, forming a pattern of a certain relationship that will be presented (data display) in the form of a narrative.

The Data obtained from each respondent is then compared and analyzed with the results obtained from the respondents in the other. The result will be in the form of a generalization which is manifest as the conclusion of the final, and can be called also as the theory that is ready to be tested in further studies.

\section{A Review Of The Results Of Data}

\section{Analysis}

Of the five research questions that have been submitted to the respondents in the interview process, it turns out that found the answers that resembles and answers that vary among the sixth of the respondents 
studied. Here is the interconnectedness of the answers of respondents with obstacles that occur in the implementation of discipleship in the church-the church-based mandarin.

Of the questions related to the understanding of respondents to the great mission it turns out that all the respondents agree that the great mission is a command to be done for the sake of obedience to Jesus Christ, even though a respondent (R2) states in addition to as compliance also to satisfy the longing of soul-winning. From both of these reasons, none of which correlated directly with hindrance factors in the implementation of discipleship.

As with the understanding of the respondents about the essence of the great mission is about discipleship or about evangelism. Indeed, all respondents agree that discipleship (as it is written in Matt.28:19-20) and evangelism (as it is written in Acts.1:8, Mrk.16:15 and Luke.24:47-48) are the same-the same is the core of the great mission, but there are two camps that have expressed some differences of opinion about the unity of the two. The stronghold of the first to assume that discipleship and evangelism are two different commands contained in the great mission, but the two can not be separated from one another, and joined in a sequence (sequence), although the sequence can be interchangeable to a certain extent. For example discipleship can be reserved for people who do not believe, but she can proceed to the next step after he claimed to believe. Stage introduction to Christ should be given first, but he can proceed to the stage of obedience after he became a believer. Meanwhile the others assume that discipleship and evangelism is a unity (blended).

$\mathrm{R} 2$ considers the boundaries between discipleship and evangelism is not clear because both are the pillars of church life that must be implemented simultaneously. Is R3 said that both the overlap between one another. Related to this seems to R6 can explain it with more explicit so that it is more easily understood and accepted, namely that the discipleship and evangelism is one whole, because evangelism is the product of discipleship, and discipleship is the follow-up of evangelism. However in practice can be sorted with a similar concept in 1 Corinthians 3:6 "I planted, Apollos menyiran, but God who gives the growth.”

Understanding the differences this turned out to be correlated directly with hindrance factors of the implementation of discipleship in the church-the church of mandarin. Almost all respondents agreed that a wrong understanding will hinder the realization of discipleship in the church-the church. In particular RK explains that when 
discipleship and evangelism are separated, then the consequences one would be an advantage and the other will be reduced by the portion even ignored. What's more when compared with one of the characteristic of the church-based mandarin spoken by R2 that the congregation of the Chinese church is passive in receiving teaching (in the sense of trusting fully what is expressed Servant of the Lord), then the non-sinkronan the Servants of God in understanding this will cause the resistance to discipleship because during this evangelism is more popular in the life of the ecclesiastical rather than discipleship.

Furthermore, all respondents agreed that the great mission applies to all believers to reach out to everyone of all nations (panta ta ethne), however its implementation can be started by reaching out to the representation of the peoples of the expected continuous scrolling so that everyone from all nations can be affordable all in the end. Likewise supposed to happen on discipleship in the context of the church, in which each congregation should be affordable, nevertheless it can be started by reaching out to a representation of each mission to then rolled out further to the wider environment.

There are a variety of understanding of discipleship of the respondents. R1 argues that discipleship is a guidance to the believers to be witnesses responsible. Is R2 said that discipleship is a development in stages to believers through small groups to multiply. R5 himself explained that discipleship is a briefing of the intellectual and the formation of the character of the church. R6 defines discipleship as an effort to know Christ and the life imitate Him. From different defining this no conflicting and potentially hinder the implementation of discipleship in the church of the Chinese, all of them are mutually restock.

However there are slight differences here and there from some of the respondents on the implementation of discipleship that could potentially hinder the implementation of discipleship.

One of them is about the implementation of discipleship in intensional and natural. In this case adherent to discipleship intensional often focused on the use of a program entitled discipleship in the implementation of discipleship itself. Being an adherent of discipleship natural, not exempt from the use of the program in the run pemuridannya, although the programs used are not specifically entitled discipleship.

R6 themselves as adherents of discipleship natural explaining that intentionality should not be translated in a program that is specific about discipleship, but in the form of intentions and a 
commitment to be discipled. However R6 does not deny that he still needs programs ecclesiastical other to be used as a means to disciple, although not all program ecclesiastical can sustain the implementation of discipleship.

Differences of opinion about this leads to further consequences, for example the user program of discipleship will tend to evaluate and measure the results achieved through programs of discipleship both in quality and quantity, are adherents of discipleship natural to say should not be the result of discipleship is measured to be evaluated, because discipleship is a whole life process which should not be measured both in quantity and quality, and because the values of the standard measurement is a very relative nature and can not be guaranteed.

As an example, namely that the quality of one's spirituality may be different between what is visible on the surface and what lies in the hearts. In addition the quality of spirituality, it also can fluctuate over time, so it is difficult to conduct a valid assessment.

Such a difference is thus indeed do not directly affect the delays in the implementation of discipleship in the church-the church who have never carry out discipleship by using programs discipleship specific, however it can indirectly influence the decision-making authority of the church to carry out discipleship for the church-the church results-oriented as mentioned as one of the characteristics of Chinese churches. The church-the church that thus will be considered if not achieved a desired result, then there is no point to hold discipleship, as described by some respondents.

Whereas the implementation of discipleship is not always as desired, so it is potentially occur rejection of discipleship. When discipleship is only implemented to achieve a certain result, not as obeying the great mission of Jesus (whatever the result), then it is very potential that discipleship is more likely to form the quality of life of people believe it will soon be forgotten and ignored. Another case with evangelism which is is a measurable result, and has become the benchmark of the competition in the realm of soul-winning among various religions.

Although each side has its argument respectively, but both parties still agree that discipleship should still be implemented. There is no other way to make people believe more and more like Christ than through discipleship.

When talking about the reach of discipleship, all respondents agree that discipleship in the context of the church must reach out to all the congregation. All of the respondents also have the same view 
that all the churches should be used as a disciple, but only part of the church that meets certain qualifications that can be pemurid as said by R2. However this does not absolve the church not to be a pemurid, but it was supposed to be the congregation who have not yet reached the qualifications to be willing to be equipped to become a Discipleship so he can carry out the great commission in the capacity and capability of each. From various kinds of obstacles such as described by the respondents, it can be pursed into two main things that are essential in inhibiting the implementation of discipleship in the church based mandarin as tabulated in the following table:

Table 4.3

\section{Classification Of Barriers To Discipleship}

\begin{tabular}{|c|c|c|c|}
\hline $\begin{array}{c}\text { ERROR } \\
\text { CONCEPT }\end{array}$ & $\begin{array}{l}\text { TYPES OF } \\
\text { BARRIERS }\end{array}$ & ANTROPOSENTRISME & $\begin{array}{l}\text { TYPES OF } \\
\text { BARRIERS }\end{array}$ \\
\hline $\begin{array}{l}\text { The failure of } \\
\text { church authorities } \\
\text { in capturing the } \\
\text { meaning of the } \\
\text { great mission }\end{array}$ & $\begin{array}{l}\text { Semantically, } \\
\text { Ecological }\end{array}$ & $\begin{array}{l}\text { The church that is difficult to } \\
\text { accept other figures }\end{array}$ & $\begin{array}{l}\text { Antropologis, } \\
\text { Psikologis }\end{array}$ \\
\hline $\begin{array}{l}\text { A waiver for the } \\
\text { great commission }\end{array}$ & Semantically & $\begin{array}{l}\text { It is difficult to create a } \\
\text { relationship that relational }\end{array}$ & $\begin{array}{l}\text { Psikologis, } \\
\text { Sosiologis }\end{array}$ \\
\hline $\begin{array}{l}\text { Understanding that } \\
\text { separates between } \\
\text { discipleship and } \\
\text { evangelism }\end{array}$ & Ecological & $\begin{array}{l}\text { The density of the activities } \\
\text { that have been ruling }\end{array}$ & $\begin{array}{l}\text { Sosiologis, } \\
\text { Vested Interest, } \\
\text { Antropologis }\end{array}$ \\
\hline $\begin{array}{l}\text { The concept and } \\
\text { different } \\
\text { perceptions about } \\
\text { discipleship }\end{array}$ & Semantically & Philosophy / result orientation & $\begin{array}{l}\text { Ekologis, } \\
\text { Vested Interest }\end{array}$ \\
\hline \multirow{3}{*}{$\begin{array}{l}\text { Never undergo } \\
\text { discipleship so that } \\
\text { it does not have a } \\
\text { clear concept }\end{array}$} & Mechanical & Consistency in implementation & psychologist \\
\hline & & Seniority & $\begin{array}{l}\text { Sosiologis, } \\
\text { Antropologis }\end{array}$ \\
\hline & & $\begin{array}{l}\text { Syndrome Servant of the Lord } \\
\text { when I have to divide its } \\
\text { influence }\end{array}$ & $\begin{array}{l}\text { Psikologis, } \\
\text { Vested Interest }\end{array}$ \\
\hline
\end{tabular}




\begin{tabular}{|c|c|c|c|}
\hline & & $\begin{array}{l}\text { Reluctance to leave the } \\
\text { comfort zone }\end{array}$ & $\begin{array}{l}\text { Psikologis, } \\
\text { Vested Interest }\end{array}$ \\
\hline & & $\begin{array}{l}\text { A typical church that is } \\
\text { passive in receiving teaching }\end{array}$ & Sosiologis \\
\hline & & $\begin{array}{l}\text { Centeredness of services on } \\
\text { the Servants of the Lord }\end{array}$ & $\begin{array}{l}\text { Antropologis, } \\
\text { Psikologis }\end{array}$ \\
\hline & & $\begin{array}{l}\text { The tendency of the church to } \\
\text { ask to be served rather than } \\
\text { serve }\end{array}$ & $\begin{array}{l}\text { Sosiologis, } \\
\text { Vested Interest }\end{array}$ \\
\hline & & $\begin{array}{l}\text { The influence of the life of the } \\
\text { consumptive hedonistic (self- } \\
\text { centered) }\end{array}$ & $\begin{array}{l}\text { psychologies, } \\
\text { Vested Interest }\end{array}$ \\
\hline & & $\begin{array}{l}\text { The attitude of the church that } \\
\text { covers the authenticity of his } \\
\text { life (maintain the image of the } \\
\text { self) }\end{array}$ & Psychologist \\
\hline & & $\begin{array}{l}\text { Junior always be in the } \\
\text { shadows of the influence of } \\
\text { the senior }\end{array}$ & Anthropologies \\
\hline & & The Concept Of Reciprocity & Sociologies \\
\hline & & $\begin{array}{l}\text { There is no tradition form a } \\
\text { small group that is relational } \\
\text { rather than individual }\end{array}$ & Sociologies \\
\hline
\end{tabular}

So there are 2 essential things that affect and are highly correlated against the barriers of the passing of

discipleship which successfully concluded through this qualitative study, namely the error in the understanding of the concept of the mandate of the supreme and centeredness in human beings or better known as anthropocentric. From a theoretical framework that has been successfully constructed by the researchers, it is expected that the future can be continued into the research-other research, especially quantitative to prove the hypothesis that has been built through this research.

While from the answers of respondents with regard to solutions to overcome the barriers that exist in the implementation of discipleship, can dirangkumkan suggestions the solution of a 
speculative nature, because it has never been researched and is not yet proven its validity.

In this case $\mathrm{R} 1$ advise to build a close relation to and share the vision with the authority of the church to be able to dismantle the tradition of the church to be integrated with the activities of discipleship. In addition, the empowerment of the church through the delegation of tasks and authority so that the figures of the congregation who meet the qualifications may be accepted in small groups which was built simultaneously with attention to the homogeneity of the groups for discipleship can be done well.

While R2 would like to invite the Servant of the Lord senior to perform introspection on motivation of their service, so that can accelerate the process of delegation of authority and influence to the Servants of God young and even the church has been ready to become the leader of the spiritual group-small group. R3 expressed the need to straighten the theological understanding and world view of the congregation in order to understand the essential truth of the Word of God. R4 own advise to start getting used to building small groups are relational, straighten your teaching and accelerate leadership.

Furthermore R5 expressed the need for long-term planning to build a theme that is sustainable and supports the implementation of discipleship, so that discipleship is acceptable to the congregation after a certain period of time. In addition R5 also suggested to build understanding and the same concept of discipleship, forming small groups of relational and strive to do the synergy of the activities of the other churches with discipleship.

And R6 say to do discipleship in the hierarchy of the leadership of the highest first before reaching down to socialization and the application can be run more smooth, in addition to building a community that is more homogeneous. 


\section{CONCLUSION}

From the preliminary studies that have been done by researchers such as has been outlined in the previous chapter, almost the whole of the Servants of the Lord agreed that discipleship is an important thing in the life of the ecclesiastical. However, from the results of the study of the beginning of the turns is suspected to have an error of understanding of the great mission, so that discipleship as instructed through the great mission, not done well in the church-the church of God.

For that in this thesis the author focus his research to the things that are relevant to the occurrence of barriers in discipleship in the church-the church-based mandarin, through the study of the traits and characteristics of the church-based mandarin, the excavation of an understanding of the great commission, praktikanya in discipleship, and the identification of the constraints of the respondents. Before the qualitative research conducted, the first author conducted a study of the exegesis on Matthew 28:19-20, so that it can build a foundation of understanding what Biblical discipleship, which is also supported by studies the theory which are arranged in this thesis. Furthermore, the qualitative research carried out on 6 respondents which consists of 4 pastor of the church-based mandarin and 2 academics seminary competent in the field of mission.

Furthermore, from the analysis conducted on the respondent's answers produced some conclusions relevant to the barriers of discipleship such as the failure of church authorities in capturing the meaning of the great commission, the understanding that separates between discipleship and evangelism, syndrome experienced by most of the Servants of the Lord when should divide his influence over the church, the reluctance to leave the comfort zone, centeredness of services on the Servants of the Lord, typical of the church which is passive in receiving the teaching, the tendency of the church to ask to be served rather than serve, the influence of the life of the consumptive hedonistic (self-centered), the philosophy of reciprocity, and so forth (cf. table 4.3). From all of which it can then be grouped into two large groups which is essential to its nature, namely the lack of understanding of the great mission and centeredness in human beings or anthropocentric.

Second this has become an obstacle essential in the implementation of discipleship in the church-the church-based mandarin.

If the review of the research objectives that were built since the early chapters, it can be said that this thesis has managed to 
build a theory about the barriers essential in

the implementation of discipleship, especially in the church-the church-based mandarin, namely centeredness in yourself and error an understanding of the great mission. Therefore, the theory is expected to be the basis in making strategic decisions related to the implementation of

\section{REFERENCES}

[1]. Forida G. Sitorus \& Okdriati, Rooted in Christ Yogyakarta: Yayasan Gloria, 2014 [2].Kenson Kuba, Discipleship Principles Pukalani - Hawaii, Discipleship Ministry, 2006

[3]. Bill Hull, the Complete Guide to Discipleship - Be and Make Disciples of Christ Yogyakarta, Yayasan Gloria, 2014 [4]. Michael Horton, Christless Christianity Surabaya. Momentum, 2012

[5]. Dietrich Bonhoffer, the cost of spreading science New York: Inc., 1949 [6]. Bill Hull, the Complete Guide to Discipleship - Be and Make Disciples of jesus Christ, 33.

[7]. The Bible Edition Of The Study-Study Bible Contemporary. Jakarta: The Indonesian Bible Institute, 2011.

[8]. Anderson, Neil T. Become The Church Of The Maker Muid. Yogyakarta: Yayasan Gloria, 2016 discipleship, and as a basis for further studies.related to further ideas from the research.

[9]. Barton, Ernest De Watt. The syntax of the moods and Tenses in New Testament Greek Illinois: University of Chicago press, 2003

[10]Berkhoff, Louis. Introduction to the New Testament. Grand Rapids - Michigan [11]. Christian Classics Library Ethereal, 1915

[12]. Boenhoeffer,Dietrich. Cost discipline. MacMillan Publishing Co. Inc., 1949

[11]. Boland, B. J. Intrisari, Christian. Jakarta: BPK Gunung Mulia, 2012

[12]. Borthwick, Paul. Commission Of Great Affection. Surabaya: Littur Perkantas Jawa Timur, 2016

[13]. Bungin, Burhan. Qualitative researchCommunication, Economics, Kepijakan Publlik, and the Science of soial behavior. Jakarta: Kucana Prenada Media Group, 2012

[14]. Carson, D. A \& Douglas J. Moo. Introduction To The New Testament. 
Malang: Gandum Mas, 2016

[15]. - , Heritage In D. A.

Surabaya: Momentum, 2012

[16]. Center for Evangelism and discipline.

The discipline of the 21st century. Missouri:

University Global, 2008

[17]. Chan, Franchis \& Mark Beuving. Multiply - Melipatganda. Yogyakarta:

Catalysts, 2017

[18]. Curtis, A. Kenneth, J. Stephen Lang

[19]. And Randy Petersen. 100 Events

Pendting In Christian History. BPK Gunung

Mulia, 2011

[20]. Davies, Margaret. Matthew. Sheffield

Phoenix Press, 2009

[21]. Davis, E L. Christian Discipline. Ohio: Good News Mintries, 2003

[22]. Drane, John. Memhami Poèinanjian

New. BPK Gunung Mulia, 1996

[23]. Eims, LeRoy. Pemburidan-A Lost Art.

Bandung: Bibaga Literature, 2002

[24]. Ends, Paul. Guide book Moody of theology, Malang, current liter, 2010

[25]. Free, Joseph P. \& Howard F. Vos. Archaeology and the extent of the Bible.

Gandum Mas, 2011

[26]. Hagner, Donald A. The Word Commentary-Matthew 14-28. Dallas: Book Publisher Said, 2012

[27]. Harrington, Bobby \& Josh Patrick. Guide book of discipline-the 6 Elements of the lifestyle of discipline. United States: distributed by discipleship.org, 2014
[28]. Henry, Matthew. Matthew Henry commentary on the whole Bible Volume VMatthew to John. Fleming H. Revell company, Volume V, TT

[29]. Hese, Rolf. The syntactic system of spoken Modern Greek. Museum Tusculanum Press, 2003

[30]. Hiebert, Paul G. anthropological reflections on the problems of the missionaries. Grand Rapids Michigan Books Baker, 1999.

[31]. Horton, Michael. Christianity Without Christ. Surabaya: Momentum, 2012

[32]. Hull, Bill. Jesus Christ, The Discipline. Surabaya: Littur Perkantas, 2015

[33].

A Complete Guide

Pemburidan. Yogyakarta: Yayasan Gloria, 2014

[34]. Choose Life. Book Baker, 2012

Hutabarat, Herdy N. Mentoring and Pemburidan. The Foundation Kalam Life, 2011 